\title{
Living History Through Canadian Time-Slip Fantasy
}

\author{
Bonnie Erlandson, Joyce Bainbridge
}

Time-slip fantasy is a particularly popular genre of literature with many children in grades six and seven. It is sometimes referred to as historical fantasy, time-warp fantasy, timetravel or past-time fantasy. Its strong attraction lies partly in the fact that it crosses three distinct genres (fantasy, historical fiction and contemporary realism) and takes the reader to a time that is quite distinct from current time, one that might be perceived as being less complex than today. It enables the reader to step back from contemporary life and see the struggles of human existence from a more distanced, reflective perspective. At the same time, the reader remains fully engaged with the characters and the issues with which the characters are faced. In time-slip fantasy, the travel across time is generally spurred by some unhappiness experienced by the protagonist. Contemporary readers in the 'middle years' can certainly identify with the need to get away from the routines of life when they grapple with issues that are beyond their control; issues such as body image, bullying, anxiety, divorce, death, and adolescence itself.

\section{Time-slip fantasy in the classroom}

It is the author's ability to convince readers to "suspend disbelief" that has made the study of fantasy literature controversial in some schools. Some adults do not consider children capable of distinguishing between reality and fantasy even though school curricula often state that middle years students should be able to make the distinction. Others worry that fantasy takes time away from more important kinds of reading. Time slip fantasy, however, is generally regarded as the most conservative of all fantasy literature. It does not deal with supernatural events, but uses a literary mechanism which allows young readers to imaginatively move through time.

There are two important reasons for children to read time-slip fantasy in school. First, students can develop an appreciation of the life and culture of a specific period in history. As Chouinard, Rubio and Waterston (1992) point out, "a child may slide by way of a book out of his or her own time and into a past era for one of two reasons: to gain a wider and deeper sense of the historic past or to get away from the present and its tension and pressures" (p.2). Temple, Martinez, Yokota, and Naylor (1998) believe that "Going back in time allows characters to gain first hand experience that deepens their understanding of how historical events influence the present" (p.343). Second, students generally can learn something about themselves, or others, that can help them understand their current circumstances. Frequently, the issues raised in time-slip fantasy are universal human issues and the protagonists finds ways to cope with such issues by meeting others who have faced the same issues in an earlier time.

Over the last fifteen years, historical time-slip fantasy has become an intriguing alternative to pure historical fiction. At a time when elementary social studies curricula typically do not include the formal study of history, time-slip fantasy can introduce children to historical time periods and events in fascinating ways. Today, many teachers recognize that through the use of time-slip fantasy and historical fiction, elementary school students can begin to develop an understanding of history. Downey and Levstik (1988) firmly believe that teaching history 
through narrative or story can provide a "temporal scaffold for historic understanding that is accessible even to quite young children” (p.338).

Instead of relying on textbooks for studying historical issues such as the early settlement of Canada and the role of Chinese immigrants in building the railways, teachers can offer novels that consider more than 'facts'. Historical time-slip fantasy considers the individual people who lived through such events and they consider the readers' emotions. Levstik and Barton (2001) write: "historical accounts show how events relate to each other. ... For many historical events, it is impossible to separate description from interpretation. Historical narratives always involve interpretation" (p.5). Unlike historical fiction, time-slip fantasy interprets events through the particular eyes and circumstances of a contemporary protagonist. That protagonist is a stranger to the historical period and sees events from the outside, from the same perspective as the reader. Readers can therefore quite easily feel connected to the people and situations in both the past and the present. Temple, Martinez, Yokota and Naylor (1998) say that "identification is a powerful way of learning from the text. It puts readers in the shoes of a character, makes them suffer what he or she suffers, makes them face the dilemmas that character faces and makes them feel the consequences of the choices they made" (p.45).

\section{Elements of time-slip fantasy}

Of all the elements that go together to create a good book, the element of 'believability' is most critical to the success of a fantasy story. Authors of fantasy take on the challenge of persuading their readers to believe things that are contrary to reality. Although fantasy is truly the author's imagination at work, the emotional reality of the book must ring true. Although fantasy can be strange, whimsical, and magical it must have characters, a setting, and an internal logic that make it real (Lynch-Brown \& Tomlinson, 1999).

Most critics of children's literature credit British author Philippa Pearce as being the 'Grand Dame' of time-slip fantasy. Her book, Tom's Midnight Garden (1958) is about a young boy, Tom Long, who is sent to the country to stay with relatives when his brother is taken ill with the measles. Having looked forward to a summer of play and adventure in their garden, Tom is bored and restless when he arrives at his aunt and uncle's garden-less 'flat', one of several that now occupy an old country house. One night Tom hears the antique grandfather clock strike the unusual number of thirteen and, on investigating, he finds his way to the back of the old house. Here he discovers a large and beautiful garden, and a lonely girl named Hatty. More than this, Tom realizes that he has gone back in time to the late 1800 s. On many ensuing nights, Tom finds his way back into the garden, and his visits become an obsession. He doesn't ever want his adventure to end. He soon realizes, however, that his time in the garden is limited; his newfound friend is aging over the series of visits, but he is remaining the same. Pearce (1958) writes: "Hatty's Time had stolen a march on him and had turned Hatty herself from his playmate into a grown-up woman" (p.205).

Tom learns and grows from his time in the past with Hatty, and, in the end, realizes that she is none other than Mrs. Bartholomew, the old lady who owns the house and who lives in one of the upstairs apartments. Tom develops a friendship with her, and learns even more about friendship, sharing and his own family. As Egoff (1988) says, Pearce "never forgets she is writing for children" (p.164) and, therefore, Tom's search to uncover the mystery of the garden and his 
ghost-life in it has the pace of a detective story. The story 'pattern' of Toms' Midnight Garden is basically reproduced throughout the time-slip genre.

In order to make their time-slip fantasies believable, most authors begin their novels by placing their protagonists in the present. Usually, the characters are typical contemporary boys or girls with whom the reader can identify, and the beginning of the novel is spent in drawing the reader into the characters' world and problems. Once the authenticity of this contemporary world has been established, the protagonist experiences a time shift into either the past or the future. Egoff (1988) reminds us, "It is time in the real world that stands still; the presence of the time traveler must be accounted for in the 'other' world" (p.132). Once placed into another time, the setting again becomes crucial to the believability of the fantasy, and authors expend an enormous amount of time and energy to develop 'place' in the other world. Descriptions are consistent in every detail. In fact, Norton (1989) maintains that so much detail is provided by the text that readers can create drawings that might appear on maps or in reference sources (p.79).

In historical time-slip fantasy, it is the time warp that makes the book a fantasy not the details of the history. The need to create an authentic time-shift, however, requires detailed descriptions that encourage the reader to see, to hear and to feel the surroundings. Readers must believe in the world created in the pages of the book, and in this way a time-slip fantasy becomes much like a book of historical fiction. Characters must face historically relevant problems (Lynch-Brown \& Tomlinson, 1999) as well as be situated in an authentic historical context. Authors of historical fiction engage in extensive research to obtain the rich details of a past life, and according to Temple, Martinez, Yokota and Naylor (1998) this is especially so "if the story is about a literate culture that left extensive records" (p.317). Authors are obligated to bring place and time to life for the reader by providing details that are neither romanticized nor distorted, but are as authentic as possible given what is known about the era in which the story is set. Egoff (1988) underscores this when she writes, "history cannot be tampered with" (p.132). Authors of quality time-slip fantasy must do their homework if they want their readers to find their work believable.

\section{Entry to the past}

The method of entry to the past and the return to the present become of major importance in a time-slip novel. Egoff (1988) maintains, "It is the chief and only fantasy device in the entire plot" (p.10). There are a variety of ways in which Canadian authors have engineered their protagonists' entry into a different period of time. Each entry must convince the reader that the shift in time, past to present or present to past, (present to future or future to present) is believable. The reader's need to continue the adventure must allow for the dismissal of a known fact: that travel through time, as far as we know, is not possible. Usually entry is achieved through the use of a talisman of some kind, or, as Egoff (1988) phrases it, "through a door opening in the mind of the protagonist" (p. 10). The entry constitutes a shift in reality or a shift in the perception of reality. Because the method of entry is the only fantasy element in the story, it is imperative that it be plausible and not distract the reader from an otherwise realistic story. The method of entry must, in fact, make the story even more compelling.

In A Handful of Time by Kit Pearson (1987), Patricia finds a pocket watch that had been given to her grandmother. When she winds it, she is transported back to her mother's childhood past. Patricia can only stay in the past for brief times (as long as the watch is wound and ticking). The 
first time she returns to the present, she thinks her experiences were all a dream. How could she be "spirited back thirty-five years to her mother's childhood and now, just as mysteriously, return to the present?" (p. 54). Of course Patricia comes up with the solution:

It was the watch. She had wound it up and it had taken her back to its own time. It had carried on ticking away the seconds and minutes and hours of the time it had kept when it was last wound. Then it had run down, so the other time had ended and her own time, the present, had started again where she had left it - at two o'clock. It was a logical explanation; all except for the reason it had happened. But Patricia was too exhilarated to worry about why. (p. 54)

In Cora Taylor's book, The Doll (1987), Meg moves back to her great-great-grandmother Shearer's childhood with the help of a family heirloom, a doll. Eventually Meg dismisses her supposition that it was all a dream and says, "you weren't supposed to remember dreams very clearly when you woke up"(p. 9). In addition, there were too many physical remnants of the historical time (for example, the smell of smoke, dirt and cow on her hands) for her to believe her experiences as a pioneer child were just a dream.

Lizzie, in Who is Frances Rain? by Margaret Buffie (1987) finds a child's pair of gold wire rimmed spectacles that become her means of entry to the past. Meaghan, in Barbara HaworthAttard's Dark of the Moon (1995), discovers that opening an old tin moneybox transports her to South Carolina in the year 1849. In Margaret Laurence's picture book, The Olden Days Coat (1979), Sal, who is bored and lonely while visiting her grandmother, puts on an 'olden days coat' and is transported back to the time of her grandmother's girlhood.

Hazel Hutchins in Within a Painted Past (1994), Julie Lawson in White Jade Tiger (1993) and Anne Carter in The Girl on Evangeline Beach (2000) use more complex mechanisms for the time slip. Alison, Hutchin's protagonist, has four pictures of mountain scenes hanging on the wall of her home. One day, Alison discovers the winter scene is snowing real flakes of snow. A single step toward the painting allows her to enter the painting and go back in time. When Alison decides to attempt the experience a second time, the winter scene is no longer snowing and it takes her some time to realize that the season in the past she has just visited has changed to spring. She will have to step into the spring picture this time, the one that smells of spring and mud.

The first time Jasmine, in White Jade Tiger, travels through time, she walks out through the exit door of a store in China town and straight back into the year 1881. When she unsuccessfully tries to repeat the event, she realizes that conditions must be exactly right. In order to slip through time, she must be dressed in the authentic clothing of a Chinese Coolie working on the railroad.

Michael, in The Girl on Evangeline Beach, is severely beaten by thugs at his school. His unconscious body is discovered on an abandoned railway line. As Michael slips in and out of a coma, he travels to the Acadia of 1755, courtesy of an old steam train, High Tides. The talisman Michael must hold on to, in order to return to the present, is a scarf that once belonged to his father. 
Much of the intensity of a time-slip novel is created in the method of entry to the past or future. Whether the story 'works' or not, largely depends on the believability of the method of entry: the simpler the entry, the more plausible the story. Within a Painted Past and The Girl on Evangeline Beach both have complex entries that somewhat disrupt the flow of the story. In both cases, however, a strong protagonist and intriguing events keeps the reader motivated and the story moving at a fast pace.

\section{Canadian history}

Julie Lawson's White Jade Tiger (1993) and Dark of the Moon (Howard-Attard, 1995) are examples of time-slip fantasy that explore important areas of Canadian history, the role of Chinese immigrants in the building of the trans-Canada railway and Canada's role in helping to end slavery, respectively. The events in White Jade Tiger take place in Victoria and in the Fraser Canyon of British Columbia after Jasmine, who lives in modern day Victoria, experiences a move through time that places her as a young Chinese immigrant in the late 1800s. The story foregrounds the harsh treatment of the Chinese immigrants who largely built the Canadian railroad:

They don't want us here. In Victoria we can't even work for the city. An old friend of Dragon Maker used to light the street lamps on James Bay. He was fired as soon as a white man was found to do the job. No, they don't want us. But they won't have a railroad without us (p. 89).

Lawson conveys information to her readers in many different ways. The following is written as an excerpt from a local newspaper, read aloud by a character in the story:

In July, 1882, without a horse or cart or steam 1031 Chinese using only picks, shovels, drills and wheelbarrows excavated 88,147 yards of earth, 10,081 yards of loose rock and 16,462 yards of solid rock. These men landed in Victoria three months before and had to be taught how to hold a shovel and strike a drill, some of them ascending cliffs 200 feet high with the aid of ropes to reach their work, clinging to rocks with foaming rivers beneath (p. 113).

Vivid descriptions create clear pictures, such as a morning in Victoria's 1880s Chinatown:

Horses pulling watercarts stirred up clouds of dust; peddlers hurried by with baskets hung on poles, filled with fish or vegetables; men carrying loads of clean laundry-trotted out of Chinatown to make deliveries, their bamboo poles bending up and down across their shoulders (p.85).

The story is not overwhelmed by the descriptive detail, however, and the book is fast-paced and engaging. Lawson focuses the reader on Jasmine, and how she felt as a modern young ChineseCanadian woman immersed in an unfamiliar culture.

Some faces were dark tan, some were pale, even paler than hers. Some were full and round with pug noses, some were thin and angular with high cheekbones.

Everyone had dark eyes. Everyone had a pigtail. And they all wore baggy pants and loose jackets like hers. She didn't feel the least bit conspicuous. But one thing 
struck her as odd. There weren't any women. No girls anywhere. Only merchants can afford to bring their wives from China and they keep them inside their homes. Otherwise they might be kidnapped (p.85-86).

Lawson shows how the early years of Chinese immigration created a mixture of old and new cultures: the making of medicine first practised in China, combined with "for profit" business practises in the new world.

The air was filled with the smells of fish, drying seaweed, herbs, and vegetables frying in hot oil. Through it all drifted the sweetish odour Jasmine had noticed before. Boiling potatoes? Or was it more like roasted peanuts? "What is that smell?" she asked. stores".

"Opium," Keung replied. "Raw opium is cooked here, in sheds behind the

\section{"Cooked?"}

He nodded. "In boiling water for about twelve hours, until it turns to jelly. Then it's put in cans and sold."

"But opium's a drug. Isn't it against the law?"

Keung looked surprised. "No. It's a very important business. Very profitable. There are many opium factories here and many opium dens" (p. 86).

Keung is Jasmine's trusted friend, whom she met during the early days of her time-slip. He is about Jasmine's own age and is a key figure in helping her, and ultimately the reader, to understand the historical period in which Jasmine finds herself. Keung belongs to the historical present and is able to act as an interpreter or mediator for Jasmine, performing the role of a wise and informed guide. Through Keung, Lawson brings to light two issues the Chinese immigrants had to face, prejudice and the redefining of their identity and culture. Many examples of blatant prejudice are presented throughout the book. Jasmine, for example, hears a man say, "Blown to shambles, along with the Indians and Chinamen. How many, I dunno. Indians and Chinamen were never counted" (p. 89). Jasmine asks Keung why the white men talk about them like that when they don't even know them. Keung says, "I know it hurts ... It's because they don't know us that they do talk like that" (p. 89).

The tensions between the old ways and the new ways are demonstrated in Keung's change in attitude, over time, towards his traditional Chinese culture. At first he has a strong commitment to his Chinese heritage. Jasmine wonders,

"Maybe if you cut your hair and dressed more like white people," Jasmine said. "Maybe it would be easier for you."

"Why? We're not ashamed of who we are. Besides most of us don't plan to stay here. We only came to make enough money to buy land in China. When we return to our villages we'll still be Chinese. If we cut our hair, we wouldn't be able to return at all." 
"What difference does your hair make?"

"When the Manchus conquered China 200 years ago they forced men to wear queues, like the long tails of horses. If you didn't wear a queue you'd be put to death. But also, if we cut our hair we are dishonouring our ancestors. Every part comes from them" (p. 90).

Yet, later, when Keung reaches adulthood, he cuts his hair and risks a huge scandal in order to marry a white woman. "A Chinese man married to a white woman? His family would have been as outraged as hers. They must have been very brave and very much in love to go through with it. And the Chinese were treated so badly in those days. Maybe that's why their children wanted to forget" (p. 152).

In Haworth-Attard's Dark of the Moon (1995), the protagonist, Meaghan, is transported back to South Carolina during the 1800 s, a time of slavery in the United States. Although the events that take place in the time-shift are not set in Canada, the book depicts an important aspect of Canadian history, the Underground Railway. Haworth-Attard conveys historical information to the reader throughout the novel as well as in the notes to readers provided at the back of the book. She explains how the North American slaves living in the 1800s whispered to each other about a country called Canada where they could find freedom. Although escaped slaves had to make a long journey to reach Canada, they were aided along the way by a network of both American and Canadian sympathizers who worked together to help them escape. The network was known as the 'Underground Railway' and used terms borrowed from the railway such as stations, conductors, and freight. In the Underground Railway, these terms referred to safe hiding places, guides, and the runaway slaves, respectively. The Underground Railway constituted a great cooperative effort on the part of both the US and Canada in helping to bring thousands of slaves to freedom. Many of today's Canadians are descendants of the runaway slaves or the people who helped them.

The protagonist in Dark of the Moon, Meaghan, is coming to terms with her father's death and her mother's recent re-marriage. While she is becoming accustomed to her new life in the countryside, she becomes intrigued by the rumour that their neighbour, Miss Sarah, is a witch. Meaghan decides to investigate and finds out that Miss Sarah is, in fact, an eighty-three year old woman whose family had escaped from a South Carolina plantation through the Underground Railway. Miss Sarah believes that the only way Meaghan can fully understand what it was like to be a slave is to experience it for herself. She says, "it's about picking cotton until you think your back's going to break, about fear so heavy in your belly you keep working and working. All your life hungry and tired. So very, very tired" (p. 29).

Miss Sarah provides Meaghan with a small tin box that has the power to send her back in time. Mistaken for a black girl, with "skin so light you'd have to look twice to make sure she wasn't a white girl" (p. 31), Meaghan becomes a black slave on a cotton plantation is South Carolina. She witnesses and eventually suffers the from the violent and demeaning behaviour practised by white owners against the black slaves. Meaghan works her fingers to the bone with no payment. One day, she sees the scars on her new friend Joshua's back; he has been whipped repeatedly. She hears stories about couples who were never allowed to marry and families who were routinely separated when sold. When the situation becomes unbearable, Meaghan escapes from 
the plantation with Joshua and his family. Meaghan experiences, first-hand, the family's anguish and fears as they attempt to flee through the Underground Railway. Joshua chooses to sacrifice himself in order to help his mother, younger brothers, Meaghan and her sister Laura escape. Joshua's mother's greatest sorrow was not knowing what happened to her son. Did he live to be old, or die young? If he died, where was he buried? The adventurous thrill of the escape keeps the reader fully engaged yet at the same time mindful of the characters' circumstances. Through this time slip fantasy, Haworth-Attard leads young readers to "understand about hate and the reason why black folk fought so hard for their freedom" (p. 29).

\section{Contemporary issues}

In addition to exploring history, time-slip fantasy offers its readers the opportunity to take stock of contemporary issues. Jones and Stott (2000) refer to Lawson's White Jade Tiger as “more than a technical device for moving a fairly average contemporary girl into a past era where historical events can be portrayed" (p.255). Besides being a work of historical fiction that describes the condition of Chinese railroad workers and the white prejudices against them, it is also what is often called a 'problem novel', a work of contemporary realistic fiction. The timeshifts in the story relate to the protagonist's development: to her attempts to accept the death of her mother, her father's absence and her adjustments to living temporarily with her Aunt. Jones and Stott (2000) say, "The girl can only move into a future if she discovers her roots as they extend back to Victoria's earlier years and beyond" (p. 255).

Karen Day (1992) studied three Canadian time-slip novels published in 1987: A Handful of Time, The Doll, and Who is Frances Rain? Each of the novels is a contemporary 'problem novel' whose protagonist has been upset by a divorce in the family. The girls wonder where they belong, and all escape into their families' pasts to answer the question. Day maintains that "time travel provides a place and a more ordered situation where the characters can mature" (p.46). In the end, each of the girls in these three books returns to the present with a greater sense of identity, a sense of who they are and where they belong. Their experiences in the past make them more able to cope with new situations.

The protagonists in Dark of the Moon and The Girl on Evangeline Beach also experience insights through their experiences in the past that allow them to deal more comfortably with the experiences of their "real lives". In Dark of the Moon (1995), Meaghan comes to accept her newly blended family; developing a particular closeness with her new step sister. In Carter's The Girl on Evangeline Beach (2000), sixteen year-old Michael is struggling to accept his father's death and the changes it has created within his family. Michael's mother is barely coping. She is irritable, never satisfied with anything Michael does, and seems to be more accepting of his younger brother and sister than she is of him. Michael turns to his grandfather for company and acceptance. Gramps is a widower and can talk about Grandmother with affection and ease. He hears her voice frequently, gently reminding him of how to cope, what to do. It is a trip with Gramps (on Grandmother's urging) to Grand-Pré in Nova Scotia that ignites the drama that explodes in Michael's life. Here, on Evangeline Beach, Michael sees the ghostly figure of a young woman begging for help. Months later, after being beaten by two thugs, Michael lapses into a coma and finds himself back in Grand-Pré in 1755. He meets the young woman, Marie, and the Robichaud family, who take him in from the winter cold. Although Michael falls in love with the pretty Marie, he knows he has no future there. In spite of his feelings, he is able to help 
the family to survive the violence and upheaval caused by the invasion of the village by British soldiers. Through Michael's knowledge of history, he is able to help the family stay together through the deportation of the Acadians by the British.

Day (1992) believes that time-slip fantasy can serve as a mirror for modern Canadian readers to understand the importance of their history, their land and the people with whom they belong. She maintains that when adolescents connect their own lives with past lives, they may be more able to cope with their own personal development. These beliefs are certainly supported by books such as The Girl on Evangeline Beach, White Jade Tiger and Dark of the Moon.

\section{Conclusions}

Many contemporary Canadian authors understand the value and importance of time-slip fantasy and have written time-slip fantasies for 'middle years' readers. In fact, the number of time-slip fantasy novels written in Canada is noticeably high. Many Canadian authors of time-slip fantasy have won awards for their outstanding writing; Margaret Buffie, Kit Pearson, Barbara Smucker and Monica Hughes have each won the Vicky Metcalf Award, presented annually to a Canadian author for a body of work "inspirational to Canadian youth". The Canadian Library Association Book of the Year for Children was awarded to Janet Lunn, in 1982, for The Root Cellar and to Kit Pearson, in 1988, for A Handful of Time. The Doll, written by Cora Taylor, won the Ruth Schwartz Children's Book Award in 1988, and the Canadian Library Association Young-Adult Book Award was presented to Margaret Buffie for Who is Frances Rain? in 1989. In 1994, the Sheila Egoff Children's Literature Prize went to Julie Lawson for White Jade Tiger.

Time-slip fantasy appeals very strongly to female readers, possibly because so many time-slip books have female protagonists. Most of the books noted in this paper, as well as more recent publications such as Tunnels of Time (Bishop, 2000) have female characters. There are a number of high quality Canadian time-slip novels with male protagonists, however, and these might be of more interest to male readers. If middle-years students are to have a choice of reading materials and access to books that are of interest to them, it is essential that the gender of the protagonists be considered. Time-slip novels such as Where Have You Been, Billy Boy? (Hughes, 1995), The Girl on Evangeline Beach (Carter, 2000) and The Grave (Heneghan, 2000) each have male protagonists and hence may have a greater appeal to male readers.

Because time-slip novels have been recognized for their excellence both in critical reviews and through the various awards bestowed upon them, reading a variety of time-slip novels to study the genre itself would be a worthwhile activity for middle years students. Norton (1989) writes, "Helping students evaluate the author's ability to suspend disbelief will help them understand and appreciate the unique characteristics of fantasy" (p.81). Beyond a study of the genre itself, however, time-slip fantasy can help readers to develop insights into the human condition and capture the essence of their deepest emotions, dreams, hopes and fears. Time-slip fantasy has also proven itself to be a valuable vehicle for the study of Canadian history. It stirs emotions and adds a layer of understanding that the reader might not attain in any other way. Being able to span generations allows the reader to 'live' in two different times. Providing students with opportunities to compare the historical context of stories with their own lives may help them to identify the "universal truths" that transcend generations and recognize that some aspects of life do indeed change over time. 
The dreamer awakes; The shadow goes by;

When I tell you a tale, The tale is a lie.

But ponder it well, Fair maiden, good youth:

The tale is a lie, What it tells is the truth.

(Carter, 2000, unpaginated)

\section{Children's Books Referenced in the Paper}

Bishop, Mary Harelkin. Tunnels of Time. Regina: Coteau, 2000.

Buffie, Margaret. Who is Frances Rain? Toronto: Kids Can Press Ltd., 1987.

Carter, Anne. The Girl on Evangeline Beach. Toronto: Stoddart Kids, 2000.

Haworth-Attard, Barbara. Dark of the Moon. Quebec: Roussan Publishers, 1995.

Heneghan, James. The Grave. Toronto: Groundwood Books, 2000.

Hughes, Monica. Where Have You Been Billy Boy? Toronto: Harper Collins Publishers, 1995.

Hutchins, Hazel. Within a Painted Past. Toronto: Annick Press Ltd., 1994.

Laurence, Margaret. The Olden Days Coat. (illus. Muriel Wood). Toronto: McClelland \& Stewart, 1979.

Lawson, Julie. White Jade Tiger. Victoria: Beach Home Publishers Limited, 1993.

Lunn, Janet. The Root Cellar. Toronto: Lester \& Orpen Dennys, 1981.

Pearce, Philippa. Tom's Midnight Garden. London: Oxford University Press, 1958.

Pearson, Kit. A Handful of Time. Markham, Ontario: Penguin Books Canada Limited, 1987.

Smucker, Barbara. White Mist. Toronto: Irwin Publishing, 1985.

Smucker, Barbara. Garth and the Mermaid. Toronto: Viking, 1992.

Taylor, Cora. The Doll. Saskatoon, Saskatchewan: Western Producer Prairie Books, 1987. 


\section{References}

Chouinard, Daniel, Rubio, Mary, \& Waterston, Elizabeth. "Editorial: Shifts in the time-slip novel". Canadian Children's Literature, 67, p.2, 1992.

Day, Karen. "Connections in prairie fiction: Paradigms of female adolescent development". Canadian Children's Literature, 67:35-47, 1992.

Downey, Matthew T. \& Levstik, Linda S. "Teaching and Learning History: The Research Base." Social Education. (September): 336-342, 1988

Egoff, Sheila A. Worlds Within: Children's Fantasy from the Middle Ages to Today. Chicago: American Library Association, 1988.

Jones, Raymond E. \& Stott, Jon C. Canadian Children's Books: A Critical Guide to Authors and Illustrators. Don Mills, ON: Oxford University Press, 2000.

Levstik, Linda S. \& Barton, Keith C. Doing History: Investigating With Children in Elementary and Middle Schools. 2nd Edition. Mahwah, N.J.: Lawrence Erlbaum Associates, 2001.

Lynch-Brown, Carol. \& Tomlinson, Carl M. Essentials of Children's Literature, 3rd Edition. Needham Heights, MA: Allyn \& Bacon, 1999.

Norton, Donna E. “Genres in Children's Literature: Identifying, Analyzing, and Appreciating”. In Children's Literature Resources for the Classroom. Masha Kakoow Rudman, Editor. Norwood, MA: Christopher-Gordon Publishers, Inc., 1989.

Temple, Charles; Martinez, Miriam; Yokota, Junko and Naylor, Alice. Children's Books In Children's Hands: An Introduction to their Literature. Needham Heights, MA: Allyn \& Bacon, 1998. 